\title{
Accounting
}

\section{The modeling firm's value based on financial ratios, intellectual capital and dividend policy}

\author{
A. Kadim ${ }^{a^{*}}$, Nardi Sunardi ${ }^{\mathrm{b}}$ and T. Husain ${ }^{\mathrm{a}}$
}

${ }^{a}$ Faculty of Economics and Business, University of Persada Indonesia Y.A.I, Jakarta, Indonesia ${ }^{b}$ Post Graduate Program, University of Pamulang, Indonesia

\section{H R O N I C L E}

Article history:

Received March 92020

Received in revised format March

152020

Accepted May 182020

Available online

May 182020

Keywords:

Modeling firm value

Solvency

Profitability

Dividend policy

\section{A B S T R A C T}

\begin{abstract}
The firm's value becomes fundamental and important when it goes public which is a basis for investment decision. Intellectual capital as a spectrum of artificial intelligence capabilities helps us reveal patterns of big data in information-based historical data to do jobs faster and better with the help of technology. This research purposes to verify the model firm's value based on financial ratios, intellectual capital, and dividend policy. The populations in this research are on the automotive subsector companies and components that are listed in Indonesia Stock Exchange (IDX) over the period 2010-2019 and eleven companies met the requirements for sampling. Methods of data analysis is based on path analysis and Sobel test which comprise the classical assumptions test, linearity test, the total coefficient of determination and estimation, and hypothesis test through direct and indirect effect. The results of this research indicate that the firm's modeling value based on financial ratios, intellectual capital and dividend policy with outcome findings of financial ratio's viz. liquidity, solvency and profitability ratio did not significantly influence the dividend policy, while dividend policy had a significant influence on firm's value. Furthermore, financial ratios mediated by dividend policy were only influenced by solvency and profitability ratios while the liquidity ratios and intellectual capital factors were not significant effects.
\end{abstract}

\section{Introduction}

Firm value become fundamental and important for those whose shares have gone public. If viewed from the investor's side, they will provide an assessment based on market prices (market price) to a company. Any increase in operational performance and financial performance generally in public companies will have an impact on stock prices on the Exchange which will ultimately rise the overall value of corporate. Besides, the government facing the Industrial Revolution 4.0 set a strategic step by optimizing the policy of industrial zones by placing a road map of the industrial sectors which were the focus of establishing Indonesia 4.0 (Kementerian Perindustrian Republik Indonesia, 2018). This condition is certainly good news for public companies and Initial Public Offering (IPO). The release of CNBC Indonesia news records a new history that since the privatization in 1992, during 2018 until early November 2018 there were 50 (fifty) new issuers which became the record listing of shares on the Indonesia Stock Exchange (IDX) (Wareza, 2018). Every company that has good prospects will always hold its cash flow and a signal of news as information about dividend policy, the decrease in the payment ratio will result in higher cash dividends with a decrease in free cash flow (Malik \& Maqsood, 2015). While the opportunity for large-scale companies and the public to increase funding sources based on debtors and small companies will tend to retain their profit ownership as part of retained earnings, these two

* Corresponding author.

E-mail address: sak_kadim@yahoo.co.id (A. Kadim) 
techniques are used for companies to obtain funding sources to raise the value of corporate. Firms value creation should also be managed wisely and effectively in the context of returns for investors through positive net present value (NPV) and this management must be analyzed for projects that are certain to produce maximum returns through retained earnings, dividend payments, and PBV to finance investment opportunities (Farooq, Rehman, Khan, \& Bilal, 2017). Several factors that influence dividend policy include: (1) current and past profits; (2) uncertainty of earnings and earnings growth; (3) prior year's dividends; (4) The level of present and possibility the time ahead earnings and the portion or progression of dividends in the prior year's; (5) level of income; and (6) profitability (Arshad, Akram, Amjad, \& Usman, 2013). Furthermore, the efficiency of the production unit or service ratio between input and output for the production process of preeminent to boost corporate performance also requires dividend policy factors with proxies the dividend payout ratios, which is suggested by investors who would prefer high profitability ratios with prospect yields for investor (Sunardi, Hamid, Kadim, \& Natanael, 2018). Besides, shares performance through dividend policy influences on firms performance, which is opposite the dividend non-relevant of theory with dividend payout ratios in cash or ownership dividend in determined in large part by company dividends (Abdullah, Quader, \& Saha, 2018).

Several results of the above research use the company's value as an impact of the corporate dividend policy with some specific factors. The corporate dividend policy is also inseparable from the company's leverage. Leverage is one of the alternatives or organizational choices in obtaining funding, namely by using debt. Companies have a high level of leverage may have low dividend payout ratios to decrease transaction costs to external financing (Ranti, 2013). Several factors illustrate the source of dividends that come from the corporate internal environment or can be controlled by the management contained in financial ratios, viz the company's liquidity and profitability ratios which are used to assess the corporate financial capability and the corporate financial performance (Wijaya, 2017). The stability of dividend payout ratio will indicate the corporate ability to ensure the expected positive changes in earnings, which also signal to the stock price and book value of the corporate through the return of assets or proxy ROA. This profitability factor becomes important for company management to convince investors that better financial conditions will be reflected in stock prices (Husna \& Satria, 2019). Corporate will tend to attract institutional ownership compared to retail because the reason for the payment of institutional dividends will be more attractive to investors for profit after tax with different treatmentd of dividend profits and capital gains. Although this cash dividend tax does not have a direct influence on raising firms value, retained earnings have direct impacts on firms performance formulated through dividend policy (Elim, 2019).

Intellectual capital, which is a spectrum of artificial intelligence capabilities, reveals patterns of big data in information-based historical data to help people do jobs faster and better with the help of technology. This artificial intelligence assembles collective intelligence stated or point out in the community of various open-source applications to deploy connectivity and share information (Herweijer \& Waughray, 2018). The necessary of strengthening artificial intelligence derived in a process optimize modeling and company analysis will be very useful in making strategic corporate decisions. Intellectual capital is also the outcome of the transformation about tacit knowledge for organizations. It is an intangible asset whose value is the same as goodwill treatment, the government and regulators have not yet to formulat explicitly of regulations for the organization and its measurement. The release of the business framework of Deloitte Touche Tohmatsu Limited has resulted in putting the work world in a competitive condition, utilizing the potential of young people as human resources will bring enthusiasm and creativity to provide input into the company's business strategy information by involving employees and consumers increasing business performance optimally without ignoring the intellectual potential that is unemployed at all (Deloitte, 2018). Quality employees are one of the key factors needed by the company to improve company performance and improve business players. Human capital is a component in the activity report which is sufficient to allocate corporate financing in achieving company value. The importance of human capital is applied in academic research on an ongoing basis to see the linkages with other factors (Dewi \& Husain, 2019).

Modeling firms value is also used as a reference for researchers using the intellectual capital factor. The performance measurement with an accounting approach is just adequate to consider the influence between intellectual capital and performance travel to capital employed efficiency (CEE), human capital efficiency (HCE), and structural capital efficiency (SCE). Investment performance with ROA proxy based on accounting-based and Tobin's Q proxy based on markets can invent a competitive advantage for business and raise the effect of economic conditions in developing performance countries (Hamdan, 2018). The effectiveness of organizational resource management has a dynamic and interactive to the measurement of funding opportunity as dividends in dividend policy through balancing accounts of the corporate measurement system. The intellectual capital consists of a structural intellectual capital (SIC), human intellectual capital (HIC), social intellectual capital (SOIC) and relational intellectual capital (RIC). The benefits obtained from intellectual capital will have an indirect influence on corporate valuation system as a vital resource derived from structural capital (Asiaei, Jusoh, \& Bontis, 2019). Low quality intellectual disclosure is likely to benefit from poorer performance compared to companies that have better intellectual disclosure quality. Improvement of intellectual capital quality disclosure will produce information available and leads to a decrease in the cost of collecting personal information. This condition will make managers more certain and relevant to produce benefit information 
to the market and business people to increase the firm's value (Vitolla, Raimo, \& Rubino, 2019). Ownership theory states that if the company has good human resources in the form of human capital, physical capital, and structural capital it will encourage investors to be interested in investing and the value of the firms will increase. The possibility of risks such as interest and tax penalties that are the visible and the loss of the corporate reputation negatively influence the long-term sustainability of the corporate business (Holiawati \& Murwaningsari, 2019). The automotive industry in the United States at the beginning of the 21 st century has implemented outsourcing without strong industry standards to establish the technical characteristics of the product and process of codifying tacit knowledge with strong competition (Sturgeon, Memedovic, Biesebroeck, \& Gereffi, 2009). The implementation of the industrial revolution 4.0 in Indonesia creates the opportunity for the production capacity of the domestic motor vehicle industry with the concept of reducing the use of human labor for the latest technology with a flexible manufacturing system that greatly impacts the financing of operational activities (Kementerian Perindustrian Republik Indonesia, 2017). Intellectual capital is a concern for global business people until 2019 despite the global economic slowdown. Business development in the manufacturing industry sector, sub-sector of the automotive and components in Indonesia through a news release from The Association of Indonesia Automotive Industries reported that in 2017 the National GDP accounted for almost $10.16 \%$ through the production of four-wheeled vehicles reaching 1.2 million (317,000 among were exported) while the number of two or three-wheeled motorized vehicles was around 6.3 million with 435,000 of them being exported (Azka, 2018). Based on data from the Central Bureau of Statistics and The Indonesian Motorcycle Industry Association (AISI), the mean of motor vehicle production unit during 2000-2016 years was a majority categorized motorcycle a amount of 88,854,863 units.

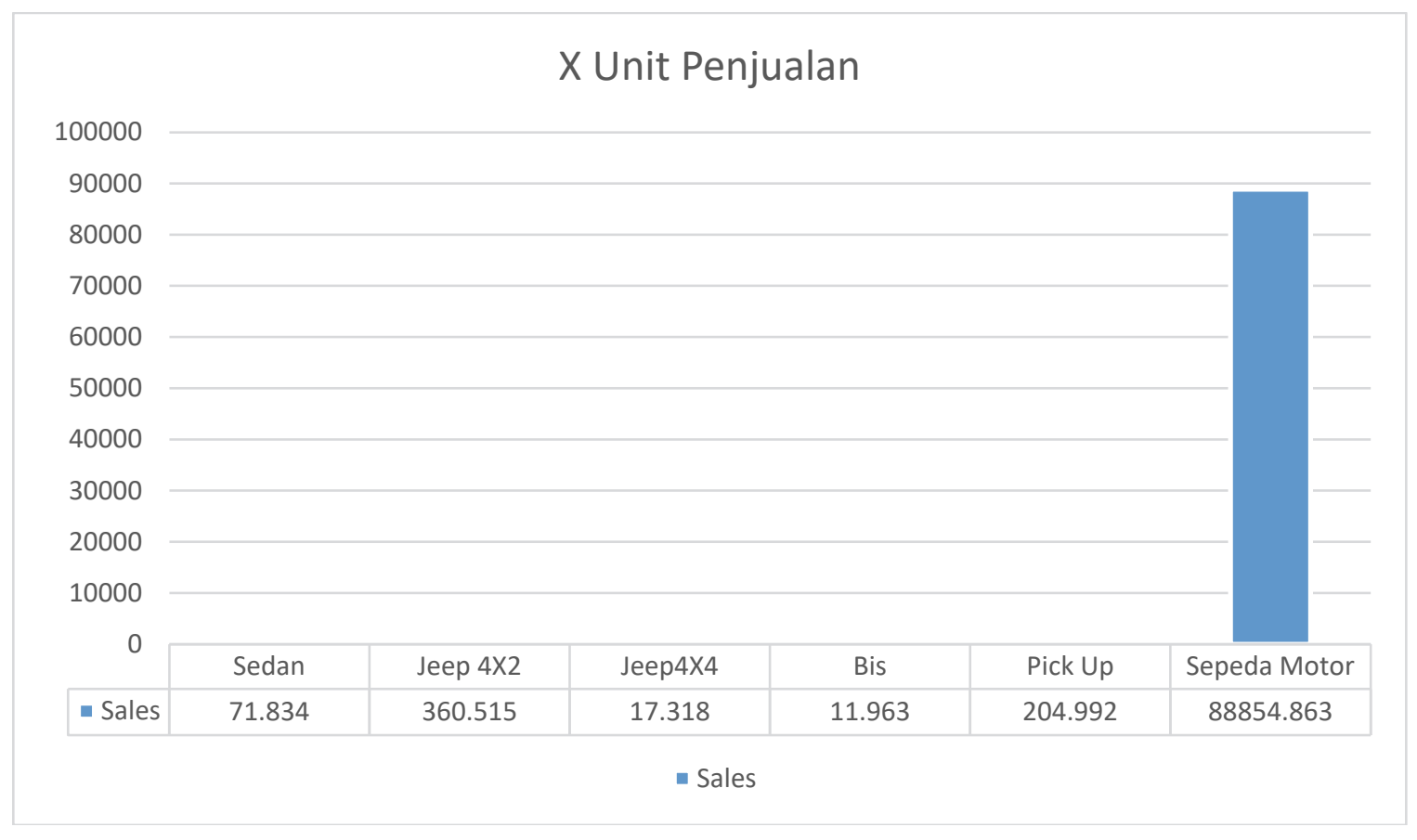

(Source: BPS Data, 2020)

Fig. 1. Average Domestic Vehicle Production in Indonesia 2000-2016

The Indonesian Automotive Industry Association (GAIKINDO) will remain optimistic in the car sales target at 1.1 million units with the passenger car market share (GAIKINDO, The Association of Indonesia Automotive Industries, 2018). There are uncertainties from global geopolitical and financial development policies that have downside risks in the context of job creation, economic growth, and sustainable development. One of the issues highlighted at the World Bank Development Committee meeting on October 13, 2018, in Bali was human capital which was lapped with Human Capital Index (HCI) products to be ready to compete with the transformation of technological change. (Holiawati \& Murwaningsari, 2019). According to the release of Ministry of Industry of the Republic of Indonesia, export achievements up to July 2019 recorded that CBU and CKD exports recorded as many as 347 thousand units and components of more than 86.6 million pieces, which has exceeded 50 percent of export achievements in 2018. This industry is increasingly supported by 1,500 companies and 240 of them are members of the Association of Car and Motorcycle Equipment Industries (GIAMM) and 122 companies are members of the Association of Small and Medium Automotive Components Industry (PIKKO). Besides, the automotive industry contributed Gross Domestic Product by 10.16 percent in 2017 with a target of 1.29 million vehicles by 2020 (Kementerian Perindustrian RI, 2019). Firms value modeling has always been the main domain for academics and practitioners who are interested in analyzing, reviewing and doing research by involving a set of factors such as financial ratio factors, dividend policies, and intellectual capital with 
certain measurements. Financial ratio factors that influence the dividend policy and the firm's value are: (1) Liquidity by measuring net asset values to increase net cash dividends which will be a bad news signal to increase corporate value (Malik \& Maqsood, 2015); and techniques to maintain its profit ownership as part of retained earnings to obtain funding from dividend policies to increase the firm value to investors through a positive NPV to finance investment opportunities (Farooq, Rehman, Khan, \& Bilal, 2017). (2) Leverage is one alternative in obtaining funding, by using debt from companies that have long financial leverage mind to have a short dividend payout ratio to diminish transaction costs correlated with external funding (Ranti, 2013). (3) Profitability to improve company performance through the efficiency of production units or services with high profitability ratios with the expectation of high returns in convincing investors (Sunardi, Hamid, Kadim, \& Natanael, 2018). (4) High profitability makes the company able to support its workings with funds from the internal company, and the company would not need funds from debt (Kadim \& Sunardi, 2018), this signal will be given entirely to investors that the return on assets as stated in the firm's performance in stock prices (Husna \& Satria, 2019).

Intellectual capital concerning to corporate value has been carried out to produce several findings, namely: (1) The purpose of intellectual capital is to examine the profitability based on iB-VACA, iB-VAHU, and iB-STVA in subject PT Bank Maybank Syariah Indonesia (BMSI) as long as 2012-2016 with the result that iB-VACA and iB-STVA have negative and insignificant influence towards ROA, while iB-VAHU have negative and insignificant effects on the ROA (Kadim, Zain, \& Sumarjaya, 2017). (2) The effect of intellectual capital and corporates performance through capital employed efficiency (CEE), human capital efficiency (HCE), and structural capital efficiency (SCE) on the firm's performance based on accounting (ROA) while there is no correlation between intellectual capital and market-based performance (Tobin's Q) (Hamdan, 2018). (3) The measurement system that uses a balancing account only proves the effect of structural capital (SIC) which has an indirect reaction on the measurement of financial performance with dimensions of ROI, profitability, cash flow from operating activities, control costs, new product development, sales volume, market share, market development (Asiaei, Jusoh, \& Bontis, 2019). (4) The relationship among the quality of intellectual capital disclosure and corporates performance in the accentuation of consolidated reporting which will reduce the cost of collecting personal information (Vitolla, Raimo, \& Rubino, 2019). The lack of modeling-based research is the background of this research to develop a model based on partial aspects that have been studied previously. This study combines the three factors above, namely financial ratio factors, dividend policy and intellectual capital using research subjects in the automotive sub-sector companies and components in the 2010-2019 research range. These industry are considered to involve the value added factor of employee capital to produce a better company performance in order to produce automotive products in a sustainable manner. The difference between this study and previous research is the modeling of firms value in this study using Tobin'Q and PBV measurements, while the financial ratio factor uses company liquidity and leverage, dividend policy still uses dividend payout ratio and intellectual capital measurement which only focuses on the valueadded capital employee (VACA). Besides, it provides a better model and time of implementation of IFRS-based Financial Reporting Standards (International Financial Reporting Standard) which has been effective as a whole since 2013 in Indonesia to answer and several weaknesses of previous research.

\section{Theoretical and Literature review}

\subsection{Concept of Modeling Firms Value}

Firms value which is the current value of supposing free cash flow discounted a weighted featureless cost of capital (Brigham \& Houston, 2016, p. 589). The Firm's value can be ascertained using the ratio analysis model approach posit market value i.e. price/cash flow ratio (PCFR), price-to-earnings ratio (PER), market book ratio (MBR), and price-to-book value ratio (PBVR).

Price-to Cash Flow Ratio (PCFR)

The price/cash flow ratio provides an investor often look stock price is tied more closely to cash flow rather than net. The $\mathrm{P} / \mathrm{CF}$ ratio is computed as follows:

(Brigham \& Houston, 2016, p. 116)

$$
\text { Price } / \text { cash flow }=\frac{\text { Price per } \text { share }}{\text { Cash flow per share }}
$$

Price-to Earnings Ratio (PER)

The price/earnings $(\mathrm{P} / \mathrm{E})$ ratio is customarily used to estimate the owners' sizing up of share value. The $\mathrm{P} / \mathrm{E}$ ratio operations the size that investors are disposing to emolument for each dollar of corporates incomes. The level of this ratio specifies the standard of confidence that investors have in the corporate's the time to come performance. The higher the P/E ratio, the greater the investor confidence. The $\mathrm{P} / \mathrm{E}$ ratio is computed as follows: 
(Gitman \& Zutter, 2015, p. 82)

$$
\frac{P}{E} \text { Ratio }=\frac{\begin{array}{c}
\text { A. Kadim et al. /Accounting } 6(2020) \\
\text { Market price per share of common stock }
\end{array}}{\text { Earnings per share }}
$$

Market Book Ratio (MBR)

The market/book (M/B) ratio customarily considers how investors sight the corporate's performance. It links the market share of the corporate's stock to their book—strict accounting — value. The M/B ratio is computed as follows:

$$
\text { Book value per share of common stock }=\frac{\text { Common stock equity }}{\text { Number of shares of common stock outstanding }}
$$

(Gitman \& Zutter, 2015, p. 83)

Price-to Book Ratio (PBV)

The price/book ratio estimates the market value of a share of stock to its book value per share. The $\mathrm{P} /$ book ratio is computed as follows:

(Titman, Keown, \& Martin, 2013, p. 123)

$$
\text { Price } / \text { book ratio }=\frac{\text { Market price per share }}{\text { Equity book value per share }}
$$

This ratio proxy was deployed by professor James Tobin as an alternative used to measure a firm's value. This ratio is a very useful abstraction because it shows the contemporary financial market customarily of the return on every dollar of incremental investment. Tobin's Q is computed by collating the ratio of the corporate stock market value with the book value of the corporate equity is computed as follows:

$$
\text { Tobin's } Q=\frac{\text { market value of equity }+ \text { DEBT }}{\text { TA }}
$$

Explanation:

Tobin's Q

MPV

DEBT

: Tobin's Q Ratio

: market value of equity

TA

: Debt

: Total Asset

(Klapper \& Love, 2004; Weston \& Copeland, 2010)

\subsection{Financial Ratio's}

Liquidity Ratio's

The net-working capital (NWC) ratio is regularly sighted as the aggregate of short-term liquidity a firm has a relatively low value that indicate low levels of liquidity. Current liabilities are diminished from current assets in reaching working capital. In using working capital and the present ratio, the point of view is one of liquidation and not of unceasing operations, this is because in usual operations current liabilities are not paid off but are of a indemnify nature. Provided sales carry on stable, both current liabilities and purchases should remain steady (Subramanyam, 2014, hal. 558). The NWC ratio is computed as follows:

$$
\text { Net Working Capital to Total Assets }=\frac{\text { Net Working Capital }}{\text { Total Assets }}
$$

(Nelson, 2008, p. 458; Ross, Westerfield, Jaffe, \& Jordan, 2016)

\section{Solvency Ratio's}

The total debt to total capital ratio is associated with operations of a capital structure connected components of capital structure to total mutually. This ratio is called namely by financial leverage points to the aggregate of debt financing in a firm's capital structure. The DER ratio is computed as follows:

(Subramanyam, 2014, p. 569)

$$
\text { Total Debt Ratio }=\frac{\text { Total Debt }}{\text { Total Capital }}
$$




\section{Profitability Ratio's}

The return on total assets is associated with operations of the generally effectiveness of management in produce profits with its available assets. The ROA ratio is computed as follows:

(Gitman \& Zutter, 2015, p. 81; Brigham \& Houston, 2016)

$$
R O A=\frac{\text { Net Income }}{\text { Total Assets }}
$$

\subsection{Intellectual Capital}

Explanation:

IB-VACA

IB-VA

$$
\mathrm{IB}-\mathrm{VACA}=\frac{\text { Value Added }}{\text { Capital Employee }}
$$

$\mathrm{CE}$

(Ulum, 2017, p. 45)

: Value-Added Capital Employed (the ratio of IB-VA to CE)

: Value-Added

: Capital Employment (available funds - equity, net income)

\subsection{Dividend Policy}

The dividend policy (DP) supposes the time ahead dividends the stockholder's desire to acquire from the retention of firm earnings. The question is dividend policy influences the share, prices raise a question as to whether dividends paid to stockholders are several more "certain". The DPR ratio is computed as follows:

(Titman, Keown, \& Martin, 2013, p. 259)

$$
\mathrm{DPR}=\frac{\text { Dividend }}{\text { Net Income }}
$$

\subsection{Research Model}

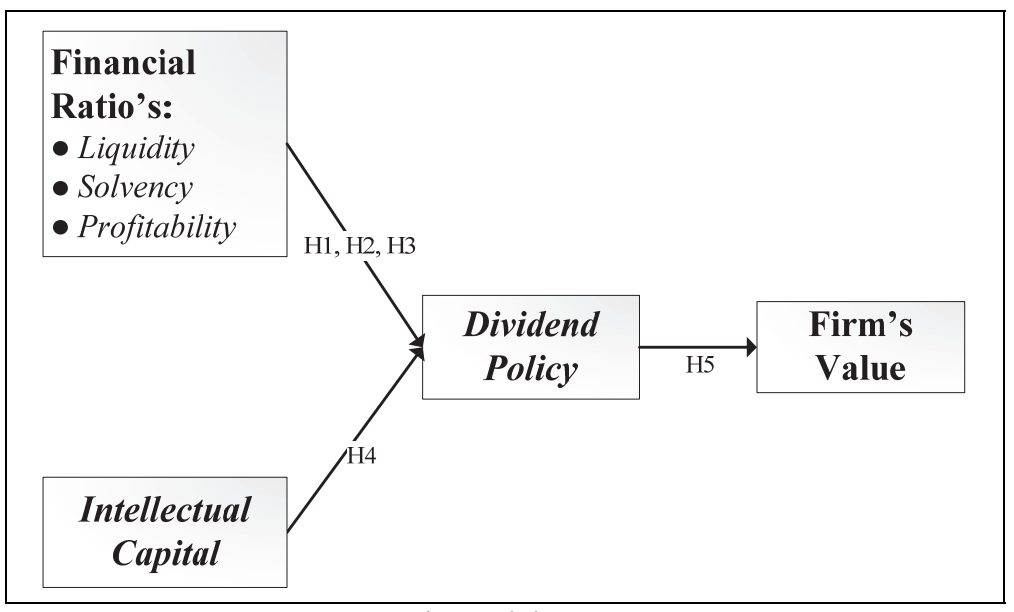

Fig 2. Research Model

To answer the research question, this study uses two model regressions:

Model 1: Studies the influence of dividend policy viz. financial ratios of NWC on liquidity, DER on solvency, ROA on profitability, and so value-added capital employee (VACA) on intellectual capital (through H1, H2, H3, and H4). Besides, it studies the influence of dividend policy on the firm's value (through H5).

Model 2: Studies the impact of the firm's value by dividend policy, which means there is an intervening function viz. financial ratios and intellectual capital $(\mathrm{H} 6=\mathrm{H} 1 \rightarrow \mathrm{H} 5, \mathrm{H} 7=\mathrm{H} 2 \rightarrow \mathrm{H} 5, \mathrm{H} 8=\mathrm{H} 3 \rightarrow \mathrm{H} 5$ and $\mathrm{H} 9=\mathrm{H} 1 \rightarrow \mathrm{H} 5)$.

\section{Research Methodology}

\subsection{Research Design}

The study deals with the time series between 2010 and 2019, which is the part of manufacturing industries in sub-sectors of automotive and component of 13 companies listed on the Indonesian Stock Exchange (IDX). Data collection methods used are 
documentation techniques by collected secondary data obtained incorporated through International Capital Market Directory (ICMD), IDX websites, and each of official website companies.

\subsection{Variables of Measurement}

Table 1

Operationalization of Variable

\begin{tabular}{|c|c|c|c|c|}
\hline \multirow{2}{*}{$\begin{array}{l}\text { Variable } \\
\text { Model }\end{array}$} & \multirow{2}{*}{ Proxy } & \multirow{2}{*}{ Abbreviation } & \multicolumn{2}{|c|}{ Impact } \\
\hline & & & Measurement & Sign \\
\hline \multirow{2}{*}{ Liquidity } & \multirow{2}{*}{ NWC } & \multirow{2}{*}{ Independent } & Net Working Capital & $-/+$ \\
\hline & & & Total Assets & \\
\hline \multirow{2}{*}{ Solvency } & \multirow{2}{*}{ DER } & \multirow{2}{*}{ Independent } & Total Debt & $+/-$ \\
\hline & & & $\overline{\text { Total Capital }}$ & \\
\hline \multirow{2}{*}{ Profitability } & \multirow{2}{*}{ ROA } & \multirow{2}{*}{ Independent } & Net Income & $+/-$ \\
\hline & & & $\overline{\text { Total Assets }}$ & \\
\hline \multirow{2}{*}{ Intellectual Capital } & \multirow{2}{*}{ VACA } & \multirow{2}{*}{ Independent } & Value Added & $+/-$ \\
\hline & & & $\overline{\text { Capital Employee }}$ & \\
\hline \multirow{2}{*}{ Dividend Policy } & \multirow{2}{*}{ DPR } & \multirow{2}{*}{ Intervening } & Dividend & $+/-$ \\
\hline & & & $\overline{\text { Net Income }}$ & \\
\hline \multirow{2}{*}{ Firms Value } & \multirow{2}{*}{ TobinsQ } & \multirow{2}{*}{ Dependent } & MVE + DEBT & $+/-$ \\
\hline & & & TA & \\
\hline
\end{tabular}

Source: Output form SPSS 24.00

\subsection{Data Analysis Methods}

In this research, we use path analysis methods. Besides that, this method can be analyzed with the Sobel test technique to see indirect effects or test the impact of firms' value models.

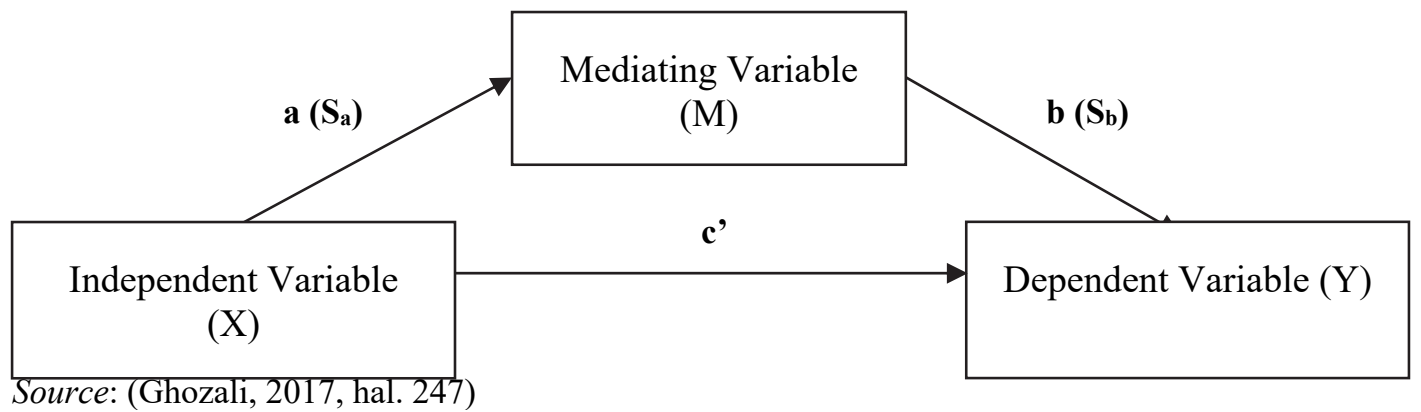

Fig. 3. The relationship betwixt Independent and Dependent Variables with the Effect of Mediator (Intervening) Variables

\section{Research Findings and Discussions}

\subsection{Descriptive}

\section{Table 2}

Statistic Descriptives

\begin{tabular}{|c|c|c|c|c|}
\hline & $\begin{array}{c}\text { Minimum } \\
\text { Score }\end{array}$ & $\begin{array}{c}\text { Maximum } \\
\text { Score }\end{array}$ & $\begin{array}{l}\text { Mean } \\
\text { Score }\end{array}$ & $\begin{array}{l}\text { Std. Deviation } \\
\text { Score } \\
\end{array}$ \\
\hline$\overline{\mathrm{NWC}}$ & -0.2866 & 0.5398 & 0.135651 & 0.1727332 \\
\hline DER & 0.0723 & 8.2600 & 1.126663 & 1.0660595 \\
\hline $\mathrm{ROA}$ & 0.0674 & 0.8920 & 0.450692 & 0.1879840 \\
\hline VACA & 0.0594 & 2.2616 & 0.626184 & 0.4291342 \\
\hline Dividend Policy & 0.0000 & 2.2375 & 0.244110 & 0.3474001 \\
\hline Firms Value & 0.3390 & 4.2530 & 1.233455 & 0.7316233 \\
\hline
\end{tabular}

Source: Output form SPSS 24.00

The results indicated that firms value score is 1.233455 Tobins'Q. Average of net working capital to total assets, the debt-toequity ratio is 13.56 percent and 1.13 time, while the average return on assets is 45.07 percent with value-added capital employee score is 0.2441 percent. The dividend payout ratio is 24.41 percent. 

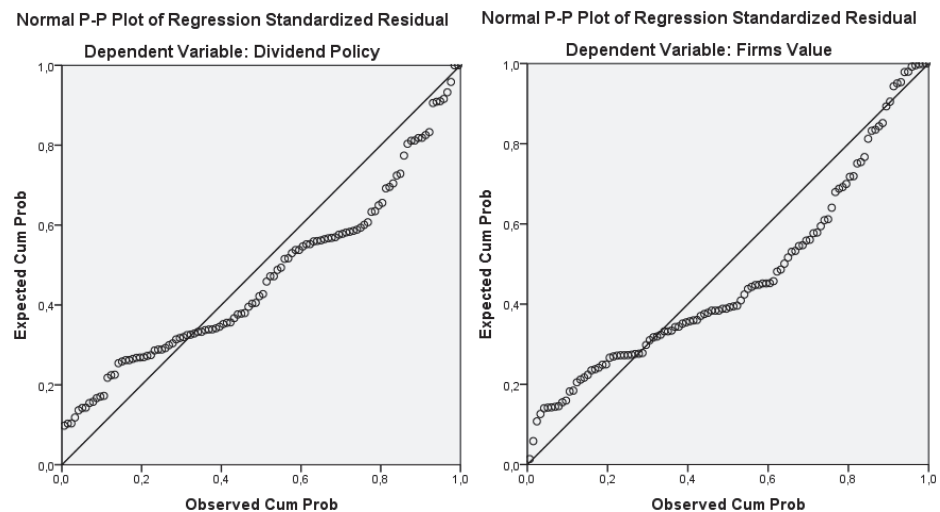

Output form SPSS 24.00

Fig 4. Normal P-Plot of Dividend Policy \& Firms Value frequency

Normality (P-Plot): The normal p-plot graph produces an unstandardized residual distribution about the crosswise line and follows the way of the crosswise line so that the residual values from the regression equation 1 and 2 models are normally distributed or have met the normality of the data.

Heteroskedastisity (Glejser Test): Heteroscedasticity test is done by replacing the residual value of regression Eq. (1) and Eq. (2) to absolute residual values with the subsequent equation:

$$
\begin{aligned}
& \left|\mathrm{Ut}_{1}\right|=\alpha+\beta 1 \mathrm{NWC}+\beta 2 \mathrm{DER}+\beta 3 \mathrm{ROA}+\beta 4 \mathrm{IC}+\mathrm{vt} 1 \\
& \left|\mathrm{Ut}^{2}\right|=\alpha+\beta 5 \mathrm{DP}+\mathrm{vt} 2 .
\end{aligned}
$$

\section{Table 3}

Summary of Heteroskedasticity Tests

\begin{tabular}{lcc}
\hline Variables & Coefficient Significance & Test Results \\
\hline Constant & 0.076 & \\
NWC & 0.383 & $>0.05$ Significant \\
DER & 0.754 & \\
ROA & 0.920 & \\
IC & 0.588 & \\
DP & 0.000 & \\
\hline
\end{tabular}

Source: Calculated form SPSS 24.00

Heteroskesticity (Glejser Test): The coefficient of the independent variable on the absolute residual value (ABS_Ut) is the overall variable is not significant at the 0.05 significance level so it concluded that the regression model does not have heteroscedasticity problems.

\section{Table 4}

\begin{tabular}{|c|c|c|c|c|}
\hline \multirow[b]{2}{*}{ Model } & \multicolumn{2}{|c|}{ Regression 1} & \multicolumn{2}{|c|}{ Regression 2} \\
\hline & $\begin{array}{l}\text { Tolerance } \\
\text { Score }\end{array}$ & $\begin{array}{l}\text { VIF } \\
\text { Score }\end{array}$ & $\begin{array}{c}\text { Tolarence } \\
\text { Score }\end{array}$ & $\begin{array}{l}\text { VIF } \\
\text { Score }\end{array}$ \\
\hline NWC & 0.535 & 1.871 & - & - \\
\hline DER & 0.290 & 3.453 & - & - \\
\hline ROA & 0.217 & 4.607 & - & - \\
\hline IC & 0.952 & 1.051 & - & - \\
\hline DP & - & - & 1.000 & 1.000 \\
\hline
\end{tabular}

Summary of Multicolinearity Tests

Source: Calculated form SPSS 24.00

Multicolinearity (Tolerance and VIF Score): The tolerance score for each variable is greater than 0.1 and the variance inflation factors (VIF) are smaller than 10. Therefore, the regression model was exempt from multicollinearity problems between independent variables. 
Table 5

Summary of Autocoreelation Tests

\begin{tabular}{|c|c|c|c|c|}
\hline & $\mathbf{d}_{\mathbf{L}}$ & $d_{u}$ & 4-du & dw \\
\hline Regression 1 & 1,6147 & 1,7651 & 2,2349 & 0,966 \\
\hline Regression 2 & 1,6708 & 1,7074 & 2,2926 & 0,492 \\
\hline
\end{tabular}

Source: Calculated form SPSS 24.00

Autocorrelations (Durbin Watson (dW) Score): The dW values for each Eq. (1) and Eq. (2) are 0.966 and 0.492 . The autocorrelations test provisions require that the regression model be between the value of $\mathrm{dU} \leq \mathrm{dW} \leq(4-\mathrm{dU})$. The $\mathrm{dW}$ value in the two-equation models is at $0<\mathrm{dW}<\mathrm{dL}$ which means there is no positive autocorrelations.

\subsection{Assessment of Linearity}

Linearity (Curve-Fit): Linearity test is done by complying with the assumptions in the path analysis model to assemble the exact model specifications. This test uses the curve fit - parsimony of concepts approach, which means that if all the models tested are significant or not significant, the linear function is significant, meaning that the model can be said to be linear. Model specifications are used as a basis for testing to choose between linear, quadratic, cubic, logarithmic, inverse, S, power, growth, compound, or exponential model.

\section{Table 6}

Summary of Linearity Tests (Curve Fit)

\begin{tabular}{lccccccc}
\multicolumn{1}{c}{ Regression } & $\begin{array}{c}\text { Spesification of } \\
\text { Model }\end{array}$ & $\mathbf{R}^{\mathbf{2}}$ Score & F Score & df1 & df2 & Significance & Test Results \\
\hline NWC $\rightarrow$ DP & Linear & 0,067 & 7,772 & 1 & 108 & 0,006 & Significant \\
DER $\rightarrow$ DP & Linear & 0,064 & 7,338 & 1 & 108 & 0,008 & Significant \\
ROA $\rightarrow$ DP & Linear & 0,068 & 7,302 & 1 & 108 & 0,008 & Significant \\
IC $\rightarrow$ DP & Linear & 0,001 & 0,079 & 1 & 108 & 0,779 & No significant \\
DP $\rightarrow$ FV & Linear & 0,091 & 10,828 & 1 & 108 & 0,001 & Significant \\
\hline
\end{tabular}

Source: Calculated form SPSS 24.00

Linearity (Curve-Fit): Based on the results of linearity test, it can be seen that in general between variables in this study there is a linear relationship, so that the analysis model made is feasible to be applied.

\subsection{Hypothesis of Testing}

Coefficient of Determination and Estimation: Test the coefficient of total determination $\left(\mathrm{Rm}^{2}\right)$ is done to estimate the strength of influence that occurs between the independent variables and the dependent variable.

\section{Table 7}

Summary of the Coefficient of Total Determination $\left(\mathrm{Rm}^{2}\right)$

\begin{tabular}{lccc}
\hline & R Score & R-Square Score & S.E of the Estimate Score \\
\hline Regression Model 1 & 0.307 & 0.060 & 0.3368625 \\
Regression Model 2 & 0.302 & 0.083 & 0.7007161 \\
\hline
\end{tabular}

Source: Calculated form SPSS 24.00

Standard arithmetic results error of the estimate from Regression Model 1:

$$
P e_{1}=\sqrt{1-R^{2}}=\sqrt{1-0.06}=\sqrt{0.94}=0.9695
$$

Standard arithmetic results error of the estimate from Regression Model 1:

$$
P e_{2}=\sqrt{1-R^{2}}=\sqrt{1-0.083}=\sqrt{0.917}=0.9576
$$

Based on the Coefficient of Total Determination $\left(\mathrm{Rm}^{2}\right)$ in the both regression model, it can be computed using the formula:

$$
R m^{2}=1-P e_{1}^{2} P e_{2}^{2}=1-(0.9695)^{2} \times(0.917)^{2}=0.2147 .
$$

The coefficient of total determination $\left(\mathrm{Rm}^{2}\right)$ results in 0.2147 scores, meaning that 21.47 percent of variables of firms value can be identified by variables of liquidity, leverage, profitability, and intellectual capital with the dividend policy variable as an intervening function while the remaining 78.53 percent is identified by another factor not follow in this research model. 
Table 8

Direct Effect of Hypothesis Testing

\begin{tabular}{clccc}
\hline Path & $\begin{array}{c}\text { Relationship between } \\
\text { Variables }\end{array}$ & $\begin{array}{c}\text { Standardized Beta } \\
\text { Value ( } \boldsymbol{\beta})\end{array}$ & $\begin{array}{c}\text { Significant } \\
\text { Probability }\end{array}$ & Results \\
\hline p1 & $\mathrm{H}_{1}:$ NWC $\rightarrow$ DP & 0,395 & 0,125 & No Significant \\
p2 & $\mathrm{H}_{2}:$ DER $\rightarrow$ DP & $-0,064$ & 0,256 & No Significant \\
p3 & $\mathrm{H}_{3}:$ ROA $\rightarrow$ DP & 0,064 & 0,362 & No Significant \\
p4 & $\mathrm{H}_{4}:$ IC $\rightarrow$ DP & $-0,070$ & 0,364 & No Significant \\
p5 & $\mathrm{H}_{5}:$ DP $\rightarrow$ FV & 0,636 & 0,000 & Significant \\
\hline
\end{tabular}

Source: Calculated form SPSS 24.00

Table 9

Indirect Effect of Hypothesis Testing

\begin{tabular}{clccc}
\hline Path & \multicolumn{1}{c}{$\begin{array}{c}\text { Relationship between } \\
\text { Variables }\end{array}$} & $\begin{array}{c}\text { Standardized Beta } \\
\text { Value }(\boldsymbol{\beta})\end{array}$ & $\begin{array}{c}\text { Significant } \\
\text { Probability }\end{array}$ & Results \\
\hline p6 & $\mathrm{H}_{6}:$ NWC $\rightarrow$ DP $\rightarrow$ FV & 0,2635 & 0,0663 & No Significant \\
p7 & $\mathrm{H}_{7}:$ DER $\rightarrow$ DP $\rightarrow$ FV & $-0,0519$ & 0,0459 & Significant \\
p8 & $\mathrm{H}_{8}:$ ROA $\rightarrow$ DP $\rightarrow$ FV & $-0,3041$ & 0,0428 & Significant \\
p9 & $\mathrm{H}_{9}:$ IC $\rightarrow$ DP $\rightarrow$ FV & $-0,139$ & 0,7888 & No Significant \\
\hline
\end{tabular}

Source: Calculated form SPSS Sobel 21.00

\subsection{Discussions}

The results of multiple regression models 1 and 2 (Table 8) for direct effect, financial ratio's variables have no significant influence towards dividend policy with the proxy of liquidity, solvency, and profitability. So, hypothesis (H1, H2, and H3) are rejected (significant probability more than 0.05), which means that modeling with financial ratio's factor in research is not adequate to evaluate the company's dividend policy on the automotive sub-sector companies and components that are listing in Indonesia Stock Exchange (IDX) since 2010-2019. The findings of this study do not agree with the results of the effect of financial performance and debt ratio (Ranti, 2013), the effect of profitability and liquidity (Malik \& Maqsood, 2015). On the other hand, the findings are consistent with insignificant results the effect of DPS, EPS, and NAPS to measure dividend policy (Omodero \& Amah, 2017), the effect of retained earnings to measure dividend policy (Elim, 2019). The intellectual capital variable has no significant influence towards dividend policy. So H4 is rejected too (significant probability more than 0.05 ), it means that modeling with intellectual capital with the value-added capital employee (VACA) in this research is not adequate to evaluate the company's dividend policy on the automotive sub-sector companies and components that are listing in Indonesia Stock Exchange (IDX) since 2010-2019. The findings of this study are consistent with insignificant results the variables iBVACA effect to ROA and dividend policy as moderating variable to firms value (Kadim, Zain, \& Sumarjaya, 2017; Dewi \& Husain, 2019). On the other hand, the findings do not agree with significant results that the structural capital have indirect effect through performance measurement systems variable (Asiaei, Jusoh, \& Bontis, 2019). The dividend policy with the proxy of dividend payout ratio (DPR) has a significant influence towards firm's value is measured by Tobins'Q proxy. So, H5 is accepted (significant probability less than 0,05 ), it does mean that modeling with dividend policy can be adequate to evaluate the company's dividend policy on the automotive sub-sector companies and components that are listing in Indonesia Stock Exchange (IDX) since 2010-2019. The findings of this study agree with the results of the effect of dividend policy and its consequence on shareholders substance maximization (Omodero \& Amah, 2017; Ranti, 2013), the negative significant association dividend policy with firm's value (Malik \& Maqsood, 2015), the positive significant relationship between dividend payout ratio and value of firms (Yemi \& Seriki, 2018; Sunardi, Hamid, Kadim, \& Natanael, 2018; Abdullah, Quader, \& Saha, 2018; Elim, 2019). The results of path analysis (Table 9) for indirect effect, only financial ratio's variables have significant influence towards the firm's value through the dividend policy i.e. the solvency and profitability factors. So, hypotheses (H7 and H8) are accepted (significant probability less than 0.05$)$, which means that modeling with dividend policy as an intervening function can evaluate the firm's value on the automotive sub-sector companies and components listed in the Indonesia Stock Exchange (BEI) for the period 2010-2019. The findings of this study are consistent with the results of the full effect of the CSR and stakeholders' interest and financial performance (Hunjra, 2018) and the effect of DER and implications on companies performance (Sunardi, Hamid, Kadim, \& Natanael, 2018). While the financial ratio's variable has no significant influence towards a firm's value through the dividend policy that is the liquidity factors measured by the net-working capital (NWC) ratio. So, H6 is rejected (significant probability more than 0,05 ), which means that modeling with dividend policy as an intervening function cannot evaluate the firm's value through liquidity ratio's on the automotive sub-sector companies and components listed in the Indonesia Stock Exchange (BEI) for the period 2010-2019. The findings of this study are consistent with the results of the direct effect of CR and DPR to firm value is no significant by current ratio proxies (Husna \& Satria, 2019; Vitolla, Raimo, \& Rubino, 2019). The results of path analysis (Table 9) for indirect effect, intellectual capital variables have no significant influence towards the firm's 
value through the dividend policy by the measured value-added capital employee (VACA). So, H9 is rejected (significant probability more than 0.05 ), which means that modeling with dividend policy as an intervening function cannot evaluate the firm's value on the automotive sub-sector companies and components listed in the Indonesia Stock Exchange (BEI) for the period 2010-2019 through the intellectual capital factors. The findings of this study confirm the insignificant results of the relationship between intellectual capital and performance accompanied by traditional accounting measures through HCE, SCE, and CEE (Hamdan, 2018), adoption of intellectual capital disclosure is still low despite having a positive association with corporates performance with ROE proxy (Vitolla, Raimo, \& Rubino, 2019), while intellectual capital has a positive influence towards the firm's value with Value Added IntellectualiCoefficient (VAICTM) proxy (Holiawati \& Murwaningsari, 2019).

\section{Conclusions and Recommendations}

\subsection{Conclusions}

This paper has studied the modeling firm's value based on financial ratios, intellectual capital and dividend policy on the automotive sub-sector companies and components listed in the Indonesia Stock Exchange (IDX) for the period 2010-2019 with outcome findings that overall of financial ratio's viz. liquidity, solvency and profitability ratio would not significantly influence the dividend policy, while the dividend policy had a significant influence on the firm's value. Furthermore, financial ratios mediated by dividend policy weree only influenced by solvency and profitability ratios while the liquidity ratios and intellectual capital factors were insignificant influence.

\subsection{Recomendations}

This findings are stimulating for firms managers. First, they get a firm value modeling which has an insignificant impact on companies listing in the Indonesia Stock Exchange (IDX), which is an important note for computing a company model with another measurement approach besides determinant using the dividend policy. Second, the importance of overall intellectual capital assessment namely by a value-added intellectual coefficient (VAITTM) to evaluate the modeling of firm's value and dividend policy can be developed in subsequent researchers to produce findings in subsequent models to improve the results of this study with value-added capital employed (VACA), value-added human capital (VAHU) and structural capital value-added (STVA).

\section{References}

Abdullah, M. N., Quader, S. M., \& Saha, J. (2018). Impact of payout policy on market value. International Review of Business Research Papers, 14(1), 109-131.

Arshad, Z., Akram, Y., Amjad, M., \& Usman, M. (2013). Ownership structure and dividend policy. Interdisciplinary Journal of Contemporary Research in Business, 5(3), 378-401.

Asiaei, K., Jusoh, R., \& Bontis, N. (2018). Intellectual capital and performance measurement systems in Iran. Journal of Intellectual Capital, 19 (2), 294-320.

Azka, R. M. (2018, Oktober 13). Bank Dunia Makin Fokus pada Isu Ekonomi Global, Human Capital dan Fintech. Retrieved September 22, 2019, from Finansial Bisnis: https://finansial.bisnis.com/read/20181013/9/848950/bank-dunia-makin-fokus-padaisu-ekonomi-global-human-capital-dan-fintech

Brigham, E. F., \& Houston, J. F. (2016). Fundamentals of Financial Management (14 ed.). (J. Sabation, Ed.) Boston: Cengage Learning.

Deloitte. (2018). Preparing tomorrow's workforce for the Fourth Industrial Revolution || For business: A framework for action. Johannesburg: Deloitte Touche Tohmatsu Limited.

Dewi, E. P., \& Husain, T. (2019). Pengaruh Intellectual Capital dan Kualitas Audit Terhadap Nilai Perusahaan Dengan Dividend Policy Sebagai Variabel Moderasi. ULTIMA Accounting , 11(2), 142-159.

Elim, J. (2019). Model of Firm Value - Indonesian Stock Exchange Case. International Journal of Economics and Financial Issues, 9(3), 154-162.

Farooq, M., Rehman, D. A., Khan, A., \& Bilal, M. (2017). Effect of Internal Financial Policy on Shareholders' Wealth and Firm Value. Journal of Business and Tourism, 03 (02), 235-246.

GAIKINDO, The Association of Indonesia Automotive Industries. (2018). GAIKINDO Optimistis Penjualan Mobil 2018 Capai 1,1 Juta Unit. (F. Sidik, Ed.) Retrieved September 29, 2019, from Berita GAIKINDO: https:/www.gaikindo.or.id/gaikindo-optimistispenjualan-mobil-2018-capai-11-juta-unit/

Ghozali, I. (2017). Aplikasi Analisis Multivariate Dengan Program: IBM SPSS 23 (VIII ed.). Semarang: Badan Penerbit UNDIP.

Gitman, L. J., \& Zutter, C. J. (2015). Principles of Managerial Finance (14 ed.). (D. Battista, Ed.) Boston: Prentice Hall.

Hamdan, A. (2018). Intellectual capital and firm performance: Differentiating between accounting based and market-based performance. International Journal of Islamic and Middle Eastern Finance and Management, 11(1), 139-151.

Herweijer, C., \& Waughray, D. (2018). Fourth Industrial Revolution for the Earth: Harnessing Artificial Intelligence for the Earth. United Kingdom: PwC Publisher. 
Holiawati, \& Murwaningsari, E. (2019). Intellectual Capital, Tax Avoidance and Firm Value. International Journal of Business, Economics and Law , 18(5), 219-227.

Hunjra, A. I. (2018). Mediating role of dividend policy among its determinants and organizational financial performance. (D. McMillan, Ed.) Cogent Economics \& Finance, 6(1), 1-16.

Husna, A., \& Satria, I. (2019). Effects of return asset, debt to asset ratio, current ratio, firm size, and dividend payout ratio on firm value. International Journal of Economics and Financial Issues , 9(5), 50-54.

Kadim, A., \& Sunardi, N. (2018). Eviews Analysis; Determinan Tourism, Restaurant and Hotel Company's Soundness and Performance. The 1" Inter-University Forum for Strengthening Academic Competency (IFSAC) 2018, on October 2nd-3rd 2018. 1 (1), pp. 332-340. Bandung: Lemlit Unpas Press, Universitas Pasundan.

Kadim, A., Zain, Y., \& Sumarjaya. (2017). Determinants of cost efficiency and it's implications on Sharia Bank in Indonesia profitability at the period of 2012 - 2016. International Journal of Economic Research , 14(16), 107-126.

Kementerian Perindustrian Republik Indonesia. (2018, April 26). Pemerintah Keluarkan 10 Jurus Jitu Hadapi Revolusi Industri 4.0. Retrieved Oktober 22, 2019, from Siaran Pers: https://kemenperin.go.id/artikel/19169/Pemerintah-Keluarkan-10-Jurus-JituHadapi-Revolusi-Industri-4.0

Kementerian Perindustrian Republik Indonesia. (2017, Nopember 28). Produsen Otomotif Nasional Terapkan Sistem Industry 4.0. Retrieved September 22, 2019, from Siaran Pers: https://kemenperin.go.id/artikel/18487/Produsen-Otomotif-Nasional-TerapkanSistem-Industry-4.0

Kementerian Perindustrian RI. (2019). Industri Komponen Topang Daya Saing Sektor Otomotif Nasional. Jakarta: Humas Kementrian Perindustrian.

Klapper, L. F., \& Love, I. (2004). Corporate governance, investor protection, and performance in emerging markets. Journal of Corporate Finance, 10(5), 703-728.

Malik, M. S., \& Maqsood, M. (2015). Impact of changes in dividend policy on firm's value: A case study of cement sector of Pakistan. Journal of Basic Sciences and Applied Research, 1 (4), 41-52.

Nelson, S. L. (2008). QuickBooks 2008 All-in-One Desk Reference For Dummies. Indianapolis: Wiley Publishing, Inc.

Omodero, C. O., \& Amah, K. O. (2017). Analysis of dividend policy and its impact on shareholders wealth maximization in Nigerian firms: A Study of Brewery Industry. Applied Economics and Finance , 4 (5), 1-8.

Ranti, U. O. (2013). Determinants Of dividend policy: A study of selected listed firms in Nigeria. The Journal of Change and Leadership , 17 (1), 107-119.

Ross, S., Westerfield, R., Jaffe, J., \& Jordan, B. (2016). Corporate Finance (11 ed.). (J. Haine, Ed.) New York: Mc Graw-Hill Education.

Sturgeon, T. J., Memedovic, O., Biesebroeck, J. v., \& Gereffi, G. (2009). Globalisation of the automotive industry: main features and trends. Int. J. Technological Learning, Innovation and Development, 2((Nos.1/2)), 7-24.

Subramanyam, K. R. (2014). Financial Statement Analysis (11th / International ed.). New York: McGraw-Hill.

Sunardi, N., Hamid, A. A., Kadim, A., \& Natanael. (2018). Determinant Of Cost Efficiency And It's Implications For Companies Performance Incorporated In The LQ.45 Index Listing In IDX For The Period Of 2011-2016. International Journal of Applied Business and Economic Research , 16(1), 17-28.

Titman, S., Keown, A. J., \& Martin, J. D. (2018). Financial Management: Principles and Applications. Boston: Prentice Hall.

Ulum, I. (2017). INTELLECTUAL CAPITAL: Model Pengukuran, Framework Pengungkapan dan Kinerja Organisasi. Malang: UMM Press.

Vitolla, F., Raimo, N., \& Rubino, M. (2019). Intellectual Capital Disclosure and Firm Performance: An Empirical Analysis Through Integrated Reporting. 7th International OFEL Conference on Governance, Management and Entrepreneurship (April, 5-6th) (pp. 245-255). Dubrovnik: Embracing Diversity in Organisations.

Wareza, M. (2018, Nopember 09). Rekor! Dalam Setahun Lebih 50 Perusahaan IPO pada 2018. Retrieved Oktober 22, 2019, from CNBC Indonesia: https://www.cnbcindonesia.com/market/20181109125101-17-41373/rekor-dalam-setahun-lebih-50perusahaan-ipo-pada-2018

Weston, F. J., \& Copeland, T. E. (2010). Manajemen Keuangan (Managerial Finance) (Jilid 2). (A. J. Wasana, \& Kibrandoko, Eds.) Tangerang: Binarupa Aksara Publisher.

Wijaya, E. (2017). Pengaruh Rasio Likuiditas, Rasio Profitabilitas dan Rasio Pasar Terhadap Kebijakan Dividen Pada Perusahaan Rokok. COSTING: Journal of Economic, Bussines and Accounting , 1(1), 1-11.

Yemi, A. E., \& Seriki, A. I. (2018). Retained Earnings and Firms' Market Value: Nigeria Experience. 7th International Conference on Business and Economic Development (ICBED), 9, pp. 482-496. New York - USA.

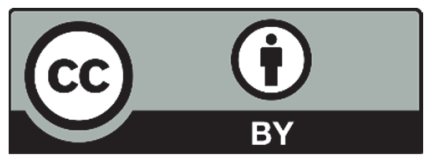

(C) 2020 by the authors; licensee Growing Science, Canada. This is an open access article distributed under the terms and conditions of the Creative Commons Attribution (CC-BY) license (http://creativecommons.org/licenses/by/4.0/). 